\title{
Wpłyu biografii językowej na idiolekt. Mowa przesiedleńców z Tarnopolszczyzny mieszkających w regionie lubuskim
}

Słowa kluczowe: biografia językowa, idiolekt, region lubuski, przesiedleńcy.

doi: http://dx.doi.org/10.31286/JP.101.4.6

\section{Wprowadzenie}

Badania przedstawione $\mathrm{w}$ niniejszym artykule dotyczą regionu lubuskiego ${ }^{1}$. Po 1945 roku na tym terenie nastąpiła wymiana nie tylko ludności, ale również języków. Tuż po II wojnie światowej funkcjonowały tu gwary przeniesione: warianty języka polskiego, białoruskiego, ukraińskiego z byłych wschodnich województw II Rzeczypospolitej oraz odmiany języka ukraińskiego i łemkowskiego (w związku z przesiedleniem w ramach akcji „Wisła”). Na obszarze obecnego województwa lubuskiego bardzo dobrze funkcjonowały gwary polskich górali z Bukowiny, gwary wielkopolskie i mazowieckie. W okolicach Babimostu odnotowano miejscowe gwary wielkopolskie (z polskiej enklawy w Niemczech). Funkcjonował również miejscowy dialekt języka niemieckiego (brandenburski), język używany przez Tatarów (Miśkiewicz 2009), język Żydów (Klatta 2012: 133) i język romski (w Gorzowie Wielkopolskim osiedliła się liczna grupa Romów) (zob. Zielińska 2012: 13; 2013: 10).

\section{Material}

Badania socjolingwistyczne w regionie lubuskim prowadziłam w latach $2009-2019^{2}$. W tym artykule zaprezentuję materiał dotyczący dwojga rozmówców, którzy po II wojnie światowej zostali przesiedleni z dawnego województwa tarnopolskiego do regionu lubuskiego. Informatorzy do 1945 roku rozmawiali w domach tylko po polsku. Język polski był ich

\footnotetext{
* gabriela.augustyniak-zmuda@ispan.waw.pl; ORCID: oooo-ooo1-9920-6663

1 Sformułowania „region lubuski” używam za Anną Zielińską, która chcąc uniknąć konotacji historycznych i administracyjnych w odniesieniu do „ziemi lubuskiej” czy „województwa lubuskiego”, określa ów teren jako „region”, co oznacza ‘jakiś obszar’ bez konieczności precyzowania rozmiarów czy granic (Zielińska 2013: 18; zob. Handke 1993: 11). 2 Artykuł stanowi część pracy doktorskiej pt. Biografie językowe przesiedleńców ze wschodnich województw II Rzeczypospolitej mieszkających w regionie lubuskim, afiliowanej przy Instytucie Slawistyki Polskiej Akademii Nauk, pod opieką promotorską prof. dr hab. Anny Zielińskiej i dr Anny Żebrowskiej.
} 
językiem prymarnym, sekundarnym ${ }^{3}$ - ukraiński (i jego odmiany). Artykuł dotyczy zatem badań, w których język traktuję jako mówienie (parole).

Na podstawie przeprowadzonych badań zaprezentuję biografie językowe rozmówców i analizę ilościową wybranych cech fonetycznych, dzięki czemu udowodnię wpływ biografii językowej na idiolekt ${ }^{4}$.

\section{Metody badawcze}

Przy pozyskiwaniu materiału zastosowałam metodę kuli śnieżnej (snowball sampling) (zob. Babbie 2009: 213), tzn. respondent wskazuje kolejne osoby, z którymi eksplorator może przeprowadzić wywiad. Jest to metoda bardzo czasochłonna, ale w badaniach wśród najstarszej generacji członków rozproszonej grupy językowej odpowiednia do sytuacji. Rozmowy przeprowadzałam w domach informatorów.

Ze względu na wiek osób biorących udział w badaniu zastosowałam wywiad biograficzny, wywodzący się z wywiadu otwartego (Kaufmann 2010: 31; zob. Schütze 1977, 1983, 1984, 1987; Hermanns 1987), który jest najbardziej adekwatną metodą w badaniu tytułowego problemu (zob. Thompson 1978; Hoffmann-Riem 1980: 343-351; Kłoskowska 2012: 117).

W celu uporządkowania etapów przyswajania i używania różnych języków w ciągu życia danego informatora wykorzystałam metodę biografii językowej (zob. Norton 20oo; Franceschini, Miecznikowski (red.) 2004; Meng 2004; Głuszkowski 2011; Busch 2017; Zielińska 2018). Termin biografia językowa rozumiem za Anną Zielińską:

Biografia językowa to historia przyswajania i używania języków w ciągu całego życia człowieka, uwzględniająca po kolei fazy jego życia (dzieciństwo, młodość, wiek dojrzały, starość) oraz wydarzenia, które wpłynęły na zmianę języka w rodzinie. Biografia językowa pokazuje wartość komunikatywną języka w ciągu całego życia mówiących. Ważne jest ustalenie, który z języków jest prymarny, a który sekundarny (2013: 68).

Na podstawie opracowań naukowych polszczyzny dawnych wschodnich województw przedwojennej Polski oraz badań prowadzonych na terenie regionu lubuskiego ustaliłam grupę cech, która stanowi bazę porównawczą dla analizy zebranego przeze mnie materiału językowego. Głównym źródłem wyboru cech były pozycje Polszczyzna na Ukrainie. Sytuacja

3 Definicję języka prymarnego i języka sekundarnego podaję według Leona Zawadowskiego: „Podstawowym językiem jest ten, który indywidualnie wykorzystuje podstawowy zakres tematu (mówienie codzienne). To język używany w domu i sferze rodziny" (1961: 14; tłum. G.A.-Ż.). Język prymarny funkcjonuje w sferze rodziny i bez pośrednictwa innego języka jest przekazywany kolejnym pokoleniom (Zawadowski 1961: 9-15). L. Zawadowski w swojej definicji nie wskazuje konkretnej liczby języków prymarnych, które może posiadać jednostka. W związku z tym jedna osoba może mieć dwa języki prymarne. Zaprezentowane podejście łączy się z rozumieniem istoty grup pierwotnych Charlesa Hortona Cooleya (1992: 209-214). Ze względu na to, że język prymarny jest przekazywany dzieciom w rodzinach tworzących grupę społeczną, można taką grupę określić za Ch.H. Cooleyem grupą pierwotną.

4 Idiolekt rozumiem jako zespół nawyków mownych jednostki (zob. Weinreich 1968: 306; Piotrowski, Ziółkowski 1976: 178), najmniejszą jednostkę w badaniach języka, odrębną i swoistą dla każdego danego systemu (Halliday 1968: 56), „język mówiony przez jednostkę" (Martinet 1961: 105). Idiolekt jest ciągłą skalą rejestrów, którymi rozmówca może posługiwać w zależności od sytuacji społecznej. Język jednostki ujawnia wewnętrzne zróżnicowanie, które jest spowodowane określonymi wzorami społecznymi (Piotrowski, Ziółkowski 1976: 184). Idiolekt można również definiować jako „lingwistyczny odcisk palca" każdego użytkownika języka. 
językowa w wybranych wsiach chłopskich i szlacheckich Ewy Dzięgiel (2003) oraz Język polski na Ukrainie w końcu XX w., autorstwa Janusza Riegera, Iwony Cechosz-Felczyk i Ewy Dzięgiel (2007). Podstawową literaturą, w której poszukiwałam danej realizacji, były publikacje, m.in.: Alojzego Zdaniukiewicza (1972), Władysława Paryla (1978), Edwarda Homy (1979), Bogusława Wyderki (2001). Wybór nie był przypadkowy. Z prac opisujących współczesną polszczyznę na dawnych ziemiach II Rzeczypospolitej wybrałam cechy, których potwierdzenia szukałam w badaniach dotyczących terenu przyłączonego do Polski w 1945 roku. Kolejno poszukiwałam tychże cech w zebranym materiale empirycznym. Zatem zadaniem było sprawdzenie, czy odnotowane współcześnie cechy na wschodzie i zaobserwowane przez badaczy zachodniej części Polski występują w mowie moich respondentów. Dążyłam do ukazania tendencji występowania danych cech we współczesnej polszczyźnie przesiedleńców. Ze szczególną uwagą zaznaczam, że artykuł nie ma na celu rekonstrukcji języka używanego przed przesiedleniem.

Analizowane w artykule cechy fonetyczne dotyczą zwężenia $o>u, e>y^{5}$ oraz $e>i^{6}$, w pozycji nieakcentowanej, asynchronicznej wymowy spółgłosek wargowych miękkich, przedniojęzykowo-zębowej artykulacji $ł$, palatalnej wymowy spółgłoski $l$ przed samogłoskami, występowania dźwięcznej spółgłoski $\gamma$ oraz palatalnej wymowy spółgłosek tylnojęzykowych.

Kanon tekstów, który został poddany analizie językoznawczej, liczy 5110 słów dla każdej osoby $^{7}$. Analizy cech fonetycznych dokonałam za pomocą metody ilościowej ${ }^{8}$. Chcąc zachować wiarygodność wyników analizy liczbowej cech fonetycznych, przyjęłam liczbę możliwości wystąpienia $[\mathrm{LM}]^{9} \mathrm{z}$ wystąpieniem rzeczywistym $[\mathrm{WR}]^{10}$. Wynik pozwolił mi na stworzenie liczbowego i procentowego podsumowania realizacji danej cechy.

\section{Biografie językowe ${ }^{11}$}

\section{Biografia językowa DS}

Kobieta urodzona w 1929 roku w województwie tarnopolskim. Mieszkała w miejscowości Rasztowce, mieszczącej się w powiecie Skałat (obwód tarnopolski). Rosztowce leżą koło Miadoborów nad rzeką Gniłą, dopływem Zbrucza. Jej rodzina po 1945 roku osiedliła się

5 Pod uwagę biorę również zwężenia $e>\dot{e}$ i $e>e^{y}$.

6 Pod uwagę biorę również zwężenia $e>e^{i}$.

$7 \mathrm{Na}$ liczbę wyrazów składają się również pytania eksploratora, które nie podlegają analizie językowej, oraz fonetyczne znaki interpunkcyjne. Wynika to $\mathrm{z}$ wyliczeń programu edytorskiego Word.

8 Metodę ilościową w pracach językoznawczych i socjolingwistycznych stosowało wielu badaczy, m.in. Iryda Grek-Pabisowa (1983) oraz we współpracy z Ireną Maryniakową (1999), Halina Kurek (1990), Elżbieta Smułkowa (2002), Anna Zielińska (2002), Ewa Golachowska (2006) oraz Kōji Morita (2006) i Mirosław Jankowiak (2009).

9 LM oznacza liczbę możliwości wystąpienia danej cechy, tzn. z treści wywiadu wyekscerpowałam wszystkie przykłady, w których użycie danej cechy byłoby i jest możliwe.

10 WR oznacza wystąpienie rzeczywiste danej cechy, tzn. z treści wywiadu wyekscerpowałam wszystkie przykłady, w których występuje dana cecha fonetyczna.

11 Przedstawienie biografii językowej rozmówcy rozpoczynam od metryki rozmówcy i przytoczenia fragmentu wywiadu dotyczącego przeszłości językowej przed przesiedleniem. Budowę biografii językowej przyjmuję za Kathariną Meng (2004). Wykorzystując różne style typograficzne, prezentuję, z jakich elementów składa się dana biografia językowa: 1) cytaty z wywiadu oznaczam kursywą, 2) terminy naukowe - pogrubieniem, 3) omówienia i podsumowania etapów życia mówcy krojem normalnym (Meng 2004: 111). W budowie biografii językowych wyodrębniam następujące etapy życia człowieka: dzieciństwo (o-6 lat), młodszy wiek szkolny (7-12 lat), dorastanie (13-23 lata), dorosłość (24-65 lat), starość (od 66 lat). Cytaty z wywiadów prezentowane są zgodnie z zachowanymi cechami języka informatorów. 
w Krasnołęgu, wsi należącej do gminy Krzeszyce (powiat sulęciński). W Rosztowcach ukończyła trzy klasy, resztę nauki kontynuowała w regionie lubuskim. Absolwentka liceum pedagogicznego. Była nauczycielką. Zmarła w 2014 roku. Pochowana na cmentarzu w Krzeszycach.

Rozmówczyni deklaruje, że językiem prymarnym przed przesiedleniem był język polski, sekundarnym - ukraiński: $v$ domu po polsku \| [na ulicy] po rusku $\|[$ [..] bo my byl'iśmy pôlakamy [...] jak udauxo śe muv'iuo po polsku \| pšyšto na voske | to fšysko po rosyjsku|po ukraińsku.

Dzieciństwo (1929-1935)

Młodszy wiek szkolny (1936-1941)
Dziadkowie: Jeden $\mathrm{z}$ dziadków był kowalem, drugi pracował na kolei (był maszynistą lub konduktorem).

Rodzice: Rodzina matki pochodziła z Czortkowa, natomiast rodzina ojca ze Skałatu. Matka i ojciec byl'i naučyćel'i | naučyćel'am'i. Poznali się podczas pracy w szkole. Rodzice pochodzili ze šlaxetnej klasy. Oprócz pracy nauczycielskiej prowadzili gospodarstwo: my mel'iśmy dužo \|dvadźeśća morgufpola. Według DS to było powodem przeniesienia rodziny do wsi Kaczanówka śe pšeńeśl’i do kačadufk'i našyx rodźicuf | bo za dužo pola mał ojćec | to pšyjex inspektor | pšeńus jego do kačadufk'i do drug'i v'osk'i.

Język: Rodzina DS $v$ domu po polsku rozmawiała, natomiast poza domem po rusku [...] tam ńe možna byú no tym | na v'esce po polsku rozmav'ać | bo byl'iby pomordoval'i. W samych Rasztowcach po polsku ne muv'il'i. We wsi byuo dv'eśće p’éńdźeśont polakuu, gdzie čšex tylko po polsku muv'iuo, w tym rodzina DS. O język polski rodźice dbal'i. Na wsi jak udaú śe muv'iuxo po polsku || pšyšło na v’oske | to f̌sysko po rosyjsku | po ukraińsku.

Komentarz: Języki em przo dków ${ }^{12}$ Ds był język polski. Był to także język prymarny rozmówczyni. Językiem kontaktów sąsiedzkich był język ukraiński.

Edukacja: W szkole w Rasztowcach nie było lekcji w języku polskim. | Jak chodziła pani do szkoły w Rasztowcach, to lekcje były po polsku? | ne || ukraińcy byl'i to značy rusk'e || [a Polaków było mało] mauno | al'e rano była rel'ig'ija f škôle | to po pôlsku muv'iło śe paćeš | a po pounudńu |jak śe šło | vyxodźiùo ze škoùy | po rusku teš paćeš był. Ds w Rasztowcach ukończyła kształcenie na etapie čé́ej klasy.

12 Terminu heritage language zaczęto używać w latach 90. Xx w. (Valdes 1995; 2000; Polinsky, Kagan 2007, za: Libura 2014: 303). Pojęcie to rozumiem za E. Dzięgiel, która traktuje heritage language w znaczeniu języka przodków, odnoszącego się do osób lub grup, które „łączy pewien rodzaj więzi z językiem własnej mniejszości narodowej, choć niekoniecznie ten język znają. Pod uwagę bierze się szerokie spektrum przypadków, od ograniczonej czynnej znajomości języka przodków (np. częściowo mówienia) bądź biernej znajomości (np. po części rozumienia), po sam udział w życiu rodzin czy społeczności, w których język ten jest używany" (Dzięgiel 2017: 207). 
Czytelnictwo: W domu rodzinnym były książki polsk’e | ruskee. W czasie napadów UPA matka fśysk'e kśonšk'i z domu povynośiła do šopy [...] i tam te kśonšk'i polsk'e | ukrainsk'e [...] banderofce jak napadl'i [...] to fšysk'e te kśonšk'i pudarl'i |pudarl'i pudarl'i i pužucal’i.

\section{Przesiedlenie (1945 r.)}

Dorastanie

(1942-1952)
Miejsce: Kiedy rodzina DS osiedlała się w Krasnołęgu, ńikogo ńe było ješče [...] my śe tu sprovadźil'i || akurat vojsko byûnô meškaù \| ješče flaga ix zostauna f kuxńi | ješče p’ivo było |fšysko. We wsi nie było osiedleńców z Rasztowców, tu byuy tak'e caukem opce [...] to ńe fšyscy jednakove pšećeš. W Krasnołęgu w szkole muj ojćec učył| był k’erovńik’em.

Język: Tuż po przesiedleniu nowi mieszkańcy Krasnołęgu to od razu po polsku začel'i [rozmawiać] [...] kalečyl'i | tak śe śm’jal'i. Dzieci przesiedleńców, które rozpoczęły naukę w szkole w Krasnołęgu, ńe bardzo dôbže mówiły po polsku, bo skont | jak sam'i rudźicey ńe umel'i.

Edukacja: Po osiedleniu w Krasnołęgu DS rozpoczęła naukę w liceum w Sulechowie. Najpierw poszła do tak'ej fstempnej klasy | to značy fstempna klasa jedna [...] al'e jak ja nap'isauam ogulnak tak'i | žeby tak'e dyktando | to petno błenduf $\|$ aš m’i śe ńe xćaù vežyć | po prostu krasa s tego červonego \|no i ńe dostauam śe. Nauczyciel skomentował to następująco: tu p’eršy tak'i ten| spotkańe z nam'i |značy tam była rosyja|ukraina | a tu polska i spotkańe s tym to bardzo trudny okres. Kiedy w Ośnie Lubuskim zaczęło funkcjonować liceum pedagogiczne, DS rozpoczęła tam naukę. Skończyła trzy klasy. W ostatniej poznała swojego przyszłego męża.

Praca: Po ukończeniu liceum pedagogicznego w Ośnie Lubuskim napisała do jednej ze szkół w Łodzi, že mam jenzyka ros \| a rusk’i bardzo |jenzyk rosyjsk’i| mam zafše p’ontk’i || no i [...] po tygodńu dostaje otpov’edź| že pšyjmom mńe. Niedługo po rozpoczęciu pracy jako nauczycielka rosyjskiego w Łodzi otrzymała pracę w Żubrowie (natomiast jej przyszły mąż rozpoczął w tym samym czasie pracę nauczyciela w Długoszynie). Szkoła w Żubrowie byuxa jednoklasufka | to fšysk'ego uczyła. Później pracowała w Krępinach, gdzie było dv’e klasy. Tam także fśysk'ego učyuam po troxe. Pracowała również w szkole w Krasnołęgu i ojćec zafšse muv'iu | a ty veźm'eš rosyjsk'i byuo | rosyjsk'i veźmeš | jenzyk rosyjsk'i i matematyk'i |bo tu juš byuna šusta klasa| to ješče matematyk'i učyuam.

Rodzina: W 1952 roku DS wyszła za mąż. W domu używano tylko języka polskiego.

Komentarz: Po przesiedleniu informatorka kształciła się w języku polskim. Dzięki nauce w liceum pedagogicznym pogłębiła znajomość polszczyzny ogólnej. 
8o | ARTYKUŁY I ROZPRAWY | JĘZYK POLSKI | CI 4

Dorosłość

(1953-1994)

Starość

(1995-2014)
Rodzina: Po urodzeniu dzieci zrezygnowała z pracy nauczyciela. Do końca życia pracowała na gospodarstwie. Od przyjazdu z Rasztowiec do śmierci używała tylko języka polskiego.

\section{Biografia językowa zS}

Mężczyzna urodzony w 1935 roku w Berezówce. Mieszkał w województwie tarnopolskim w powiecie Buczacz, w miejscowościach Berezówka i Słobódka Dolna, leżących na południowy wschód od Lwowa i na północny wschód od Stanisławowa (obecnie Iwano-Frankowsk). Po przesiedleniu mieszkał w Świętojańsku, wsi należącej do gminy Krzeszyce (powiat sulęciński) w województwie lubuskim. Pracował jako listonosz oraz był trenerem piłki nożnej w lokalnym klubie sportowym. Zmarł w 2016 roku, pochowany na cmentarzu w Krzeszycach.

Rozmówca deklaruje, że językiem prymarnym przed przesiedleniem był język polski: $j a$ po pôlsku || u nas śe |f̌sysko muv'iư po pôlsku\|.

Dzieciństwo

(1935-1941)
Rodzice: Matka zs pracowała w fabryce tam rob'il'i pap’erosy. Ojciec byu šefcem. Oboje po pôlsku gadal’i. Pochowani w Krzeszycach.

Miejsce: Językiem przodków był język polski u nas v domu po pôlsku. W Słobódce Dolnej fšysko muv'iư po pôlsku \|ta u nas byuno tylko čtery| čy to p’enć rodźin ukraińsk'ix byu $\mid$ a to $\mid$ a to same pôlacy. Językiem kontaktów między społecznością ukraińską był język ukraiński i polski: jak śe spotkau z ukraińcem | to troxu tak | troxu tak | rozum'iš || tak śe muv'iuo | al'i [...] navet $i$ ten

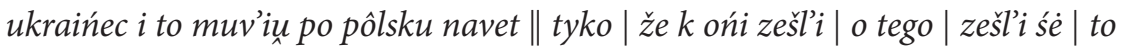
ften čas [po ukraińsku].

Religia: W Słobódce Dolnej tak na końec v’osk'i byu pôlsk’i kośćuu \| o i tam xodźili do kośćouna ludźe.

Komentarz: Językiem przodków i językiem prymarnym zs był język polski. Polacy w Słobódce Dolnej posługiwali się tylko językiem polskim. Język ukraiński służył do kontaktów między Ukraińcami, którzy tworzyli znikomą część społeczności. Znajomość języka ukraińskiego wśród Polaków była na poziomie bilingwizmu początkowego ${ }^{13}$ lub progresywnego ${ }^{14}$ prawdopodobnie znali w języku ukraińskim gotowe zwroty lub znali język w różnym stopniu biegłości.

13 Bilingwizm początkowy „dotyczy pierwszych etapów kontaktu językowego, gdy niewiele osób zna nowy język. Użycie nowego języka ograniczone jest do zestawu gotowych zwrotów na każdą okazję" (Dzięgiel 2003: 70). 


\section{Przesiedlenie (1945 r.)}

Młodszy wiek szkolny (1942-1947)

Dorastanie (1948-1958)
Edukacja przed przesiedleniem: ZS w Słobódce Dolnej čy klasy ukońčyuxem. W Słobódce Dolnej začel'i ukraincy juš | te | šum'ić | rozum'ić | tag že škouna rozv’onzaua f̌sysko \|tak že juš ńe byuo nauk'i v'ency.

Czytelnictwo: W domu zs kśonžek ńe byuxo žadnyx.

Edukacja w regionie lubuskim: Po przesiedleniu zs poszedł do szkoły i ja tutej mam śedem \|tutej [...] ja pšyjexou tu|pošed do čfartej klasy tu.

Miejsce: Rodzina zs została przesiedlona musovo | pšymusovo. Ze Słobódki Dolnej przesiedlono pôlakuu |fšysko na stacje | do vagonuu po tok dv'e | čy rodźiny vagone $i$ jexało. Rodzina zs przyjechała od razu do Krzeszyc $i$ to na śv'entojańsk pšyjexal’i. Sołtys wówczas zapewniał, że najv'encej [...] na rok času| na rok času || śe | śedźimy rok | ńikt ńe zab’era | śedźimy drug’i rok | ńikt ńe zab'era. W wywiadzie często poruszany był temat tęsknoty za rodzinnymi stronami. W 1946 roku, kiedy już całe Świętojańsko zostało zasiedlone, to fšysko po pôlsku [...] tutaj po polsku my muv'il'i.

Miejsce: ZS deklaruje, że po to ukrajińsku ja rozumaúnem troxu. Kiedy ZS pracował jako listonosz (prawdopodobnie w okolicach 1950 r.) i pošet [...] na krasnoueng |jak tak baby začel'i po tym svojim mówić. Zs nie rozumiał języka kobiet, nie wiedział, co to jest červo i xuba. Kobiety mówiły w języku wschodniosłowiańskim, prawdopodobnie po ukraińsku. zS ze słabą znajomością języka ukraińskiego nie mógł zrozumieć mowy przesiedleńczyń.

Rodzina: ZS wziął ślub w 1956 roku. Jego żoną została kobieta przesiedlona z regionu województwa stanisławowskiego, której jęz y ki e m p r y ma rn y m była mowa „chachłacka”. W rodzinie zawsze używano języka polskiego. Żona zS nauczyła się języka polskiego od swoich braci, którzy chodzili do szkoły już w regionie lubuskim. Być może z powodu nieznajomości języka ukraińskiego ani mowy chachłackiej przez ZS w stopniu komunikatywnym żona nie miała wyboru i musiała porozumiewać się z mężem tylko po polsku. Nie można jednak wykluczyć tego, że oba języki - język męża i język żony - mogły mieć na siebie znaczący wpływ.

Komentarz: Okres dorastania był kluczowym etapem w kształtowaniu się i d i olektu zs. Wpływ na to miały kontakty językowe ${ }^{15} \mathrm{z}$ przesiedleńcami

15 Pojęcia kontakt językowy używam za Urielem Weinreichem, według którego „[...] dwa lub więcej języków jest w kontakcie, jeśli używają ich na przemian te same osoby" (1970: 1; tłum. G.A.-Ż.). U. Weinreich uważa, że to właśnie w jednostce się urzeczywistnia kontakt językowy, co dotyczy indywidualnego wymiaru języka (parole). W związku z tym odnosi się do systemu (langue), ale zachodzi na stopniu jednostki (zob. Głuszkowski 2013: 19). Kontakt językowy w ujęciu grupowym jest uwarunkowany przez czynniki makrospołeczne. Jednym z nich jest położenie geograficzne, które może ograniczać kontakt językowy między różnojęzycznymi grupami, natomiast drugim jest charakter wspólnoty dwujęzycznej - język przesiedleńca jest podatny na innowacje językowe, w przeciwieństwie do społeczności rdzennej (zob. Weinreich 1970: 89-91). 
z różnych wschodnich województw. Praca listonosza przyczyniła się do zwiększenia re pertuaru jęz y k o w e g o ${ }^{16}$ zs. Bardzo ważnym wydarzeniem był ślub z kobietą, której językiem prymarnym była mowa chachłacka ${ }^{17}$. Prawdopodobnie podczas trwania małżeństwa zachodził stały proces $\mathrm{tr}$ an sfe $\mathrm{ru}^{18}$ wzorów z języka męża do języka żony i odwrotnie.

Dorosłość

(1959-2000)

Starość

(2001-2016)
Po rezygnacji z pracy listonosza zajął się pracą w gospodarstwie. Według zS ta jak o tera muv'i tak śe ù domu muv'iuxo u nas.

\section{Wybrane cechy fonetyczne}

\section{Zwężenie $o>u$ w pozycji nieakcentowanej}

W kanonie tekstów, który obejmuje 5110 wyrazów dla każdego rozmówcy, możliwość wystąpienia zwężenia $o>u$ w pozycji nieakcentowanej w idiolektach osób deklarujących mówienie po „polsku i ukraińsku” mieściła się w zakresie między 819 [LM] (w idiolekcie DS) a 515 [LM] (w idiolekcie Zs) wyrazów. W idiolekcie Ds odnotowałam 18 [WR] przykładów m.in. pudarl’i, pužucal'i, rudźicey, rub'iua

\section{Zwężenie $e>y$ w pozycji nieakcentowanej}

Możliwość wystąpienia zwężeń $e>y$ w pozycji nieakcentowanej mieściła się w zakresie między 1286 [LM] (w idiolekcie DS) a 1072 [LM] (w idiolekcie Zs) przykładów. W mowie DS wystąpiło 29 [WR] przykładów, m.in. jedèn $\left(5^{19}\right)$, kovalèm, pšénice, p’eršy [pierwsze], bratym [bratem], a w ZS 20 [WR] przykładów, np. pustè (4), tyứek, ludźé, provadźiuém (3), porotym (2), jedyn.

16 Repertuar językowy to „zbiór wszystkich form językowych używanych przez członków danej społeczności językowej” (Piotrowski, Ziółkowski 1976: 99). Najnowsze rozumienie repertuaru językowego przyjmuje perspektywę biograficzną, która wiąże repertuar z biografią językową jednostki (zob. Blommaert 2008; Blommaert, Backus 2013). „Faktem jest jednak, że czyjś repertuar językowy odzwierciedla życie, a nie tylko narodziny, i jest to życie, które toczy się w prawdziwej przestrzeni społeczno-kulturowej, historycznej i politycznej” (Blommaert 2008: 17; tłum. G.A.-Ż.).

17 Według M. Drzazgowskiego chachłacka mowa ,to potoczne określenie części gwar wschodniosłowiańskich, rozpowszechnione również na obszarze współczesnej Polski wzdłuż wschodniego pogranicza. [...] chachłacka mowa uchodzi za określenie pogardliwe, nawet obelżywe [...] uważa się potocznie tę nazwę za dziwaczną, 'byle jaką, bez wartości i tradycji [...]” (1992: 29); „jest to nazwa rosyjska, związana z okresem zaborów, przynajmniej jeśli chodzi o terytorialne rozpowszechnienie. Zapewne oznaczała wówczas niepoprawny, zepsuty język rosyjski, czego nie akceptowała ani inteligencja polska, ani ukraiński czy białoruski ruch narodowy” (ibidem: 31). W rozumieniu przesiedleńców z dawnych wschodnich województw II Rzeczypospolitej mowa „chachłacka” jest językiem mieszanym, w którym występują elementy języków polskiego, ukraińskiego i rosyjskiego. Język „chachłacki” to także często używany potoczny lingwonim określający język ukraiński i jego odmiany. W wywiadach pojawia się także określenie „ruski”, używane jako synonim zarówno ukraińskiego, rosyjskiego, jak i „chachłackiego”.

18 W Encyklopedii językoznawstwa ogólnego transfer to „[...] przenoszenie wzorów z jęz. ojczystego na jęz. obcy w procesie jego opanowywania. Zjawisko to występuje zarówno w fonetyce, jak i w gramatyce i słownictwie [...]” (EJO: 606). Przenoszenie wzorów $\mathrm{z}$ kodu $\mathrm{L}_{1}$ do $\mathrm{L}_{2}$ jest pozytywne, jeśli wzory są takie same w dwóch językach, a negatywne wówczas, kiedy są różne (zob. Zielińska 2013: 55). Transfer występuje podczas akwizycji drugiego języka (zob. Romaine 1989: 51). Pojęcia transferu używa się również w pracach, dotyczących problematyki kontaktów językowych, właśnie zamiast pojęcia interferencji (zob. Riehl 2009: 32-36).

19 Liczba wystąpień tego samego przykładu w całym kanonie tekstu. 


\section{Zwężenie $e>i$ w pozycji nieakcentowanej}

Możliwość wystąpienia zwężeń $e>i$ w pozycji nieakcentowanej mieściła się w zakresie między 1286 [LM] (w idiolekcie DS) a 1072 [LM] (w idiolekcie Zs) przykładów. W idiolekcie zS odnotowałam 44 [WR] przykłady, m.in. al’i (8), pšyjeixal'i, vel'i [wiele] (2), košul'i [koszule], kartofl'i [kartofle] (2), p’ičontke [pieczątkę]. W mowie Ds wyekscerpowałam 32 [WR] przykłady, m.in. vyjeixal'i, al'i, naučyćel'i [nauczyciele], bunońi [błonie], smakuji [smakuje], konop’i [konopie].

\section{Asynchroniczna wymowa spółgłosek wargowych miękkich}

Możliwość wystąpienia asynchronicznej wymowy spółgłosek wargowych miękkich w idiolektach osób deklarujących mówienie po „polsku i ukraińsku” mieściła się w zakresie między 234 [LM] (ZS) a 177 [LM] (DS) wyrazów. W mowie zs odnotowałam 2 [WR] przykłady (mńau, mńel'i), natomiast w idiolekcie DS 1 [WR] przykład (śem’je [siemię]).

\section{Przedniojęzykowo-zębowa artykulacja $t$}

W kanonie tekstów możliwość wystąpienia przedniojęzykowo-zębowego $l$ mieściła się w zakresie między 465 [LM] (DS) a 393 [LM] (ZS) wyrazami. W idiolekcie DS wyekscerpowałam 174 [WR] przykładów, m.in. nastrašyła, skońčyłam, zostav'iła, styšy, m’iłośći, čłov'ek. W tekstach zs można odnaleźć jedynie 8 [WR] wyrazów, na przykład xodźiła, jexało, słonko, zasło, był, ćała.

\section{Palatalna wymowa spółgłoski $l$ przed samogłoskami}

W kanonie tekstów możliwość wystąpienia tej cechy mieściła się w zakresie między 176 [LM] (DS) a 109 [LM] (ZS) wyrazów. W idiolekcie DS odnotowałam 36 [WR] przykładów, m.in. klasy, mal'utk'i, dal'eko, kavalezže, l'ep̉ej, źlé. W wywiadzie z zs [WR] wystąpiły 23 realizacje tej cechy, na przykład ale (13), v'ele (3), tyle, pol'e, xl'eba, dal'eko.

\section{Występowanie dźwięcznej spółgłoski $\gamma$}

Dźwięczna spółgłoska $\gamma$ występuje w obu idiolektach. Odnotowałam przykłady w mowie zs: yektar, yop oraz w DS yorodysk'ego ${ }^{20}$, aya, yołova.

\section{Palatalna wymowa spółgłosek tylnojęzykowych}

W kanonie tekstu DS możliwość realizacji palatalnej wymowa spółgłosek tylnojęzykowych występuje w 485 [LM] wyrazach, natomiast w języku zs 472 [LM]. Pomimo dużej liczby możliwych realizacji odnotowałam tylko 2 [WR] przykłady w rozmowie z DS: trox'e, vutkee.

Przegląd występowania wybranych cech fonetycznych wskazuje na większe lub mniejsze w zależności od idiolektu - rozbieżności w realizacji. Poniższa tabela przedstawia procentową wartość występowania danej cechy w idiolekcie. 
84 | ARTYKUŁY I ROZPRAWY | J̨̨ZYK POLSKi | CI 4

Tabela 1. Podsumowanie analizy lingwistycznej

\begin{tabular}{|c|c|c|}
\hline CECHY FONETYCZNE & DS & ZS \\
\hline zwężenie $o>u$ w pozycji nieakcentowanej & $2,2 \%$ & $0,19 \%$ \\
\hline zwężenie $e>y$ w pozycji nieakcentowanej & $2,25 \%$ & $1,89 \%$ \\
\hline zwężenie $e>i$ w pozycji nieakcentowanej & $2,47 \%$ & $4,1 \%$ \\
\hline asynchroniczna wymowa spółgłosek wargowych miękkich & $0,56 \%$ & $1 \%$ \\
\hline przedniojęzykowo-zębowa artykulacja $\ell$ & $37,42 \%$ & $2,03 \%$ \\
\hline palatalna wymowa spółgłoski $l$ przed samogłoskami & $21,82 \%$ & $21,1 \%$ \\
\hline występowanie dźwięcznej spółgłoski $\gamma$ & $100 \%$ & $100 \%$ \\
\hline palatalna wymowa spółgłosek tylnojęzykowych & $0,41 \%$ & - \\
\hline
\end{tabular}

\section{Wpływ biografii językowej na idiolekt}

Podejmując próbę odpowiedzi na pytanie, jaki jest wpływ biografii językowej na idiolekt rozmówcy, należy wziąć pod uwagę aspekty związane z przebiegiem życia mówcy:

(a) język prymarny rozmówcy - uwzględniając świadomą zmianę języka i możliwość artycji językowej $^{21}$;

(b) język przodków - czy był językiem prymarnym, czy był (lub jest) używany przez rozmówcę;

(c) język kontaktów sąsiedzkich przed przesiedleniem oraz po przesiedleniu - czy sytuacja społeczna, w której znajdował się rozmówca, miała wpływ na przykład na świadomą zmianę języka lub zachowanie języka;

(d) wykształcenie - czy rozmówca uczęszczał do szkoły przed przesiedleniem, czy kształcił się po przesiedleniu; ważną kwestią jest też pochodzenie nauczycieli, zwłaszcza w kształceniu na terenie regionu lubuskiego;

(e) wykonywany zawód - w zależności od wykonywanego zawodu rozmówca miał możliwość rozwijać swój repertuar językowy;

(e) współmałżonek i język, w jakim się porozumiewano po zawarciu małżeństwa - czy na język rozmówcy mógł mieć wpływ język żony/męża, jak rozmawiano z dziećmi i dlaczego;

(f) nastawienie do języków ${ }^{22}$ (w tym do języka używanego przez rozmówcę).

21 Atrycję językową w szerokim rozumieniu należy traktować jako utratę języka spowodowaną zapomnieniem. W wąskiej interpretacji jest to utrata języka pierwszego, nabytego w dzieciństwie, spowodowana pobytem w nowym środowisku językowym (zob. Polinsky 1995: 88; Montrul 2002: 40, za: Libura 2014: 303-312).

22 Nastawienie do języka jest elementem zależnym od biografii językowej - jest to emocjonalne podejście do danego języka, które wyraża się w używaniu nacechowanych określeń danej mowy czy jej ocenianiu. Sarah G. Thomason w pracy pt. Language contact nastawienie do języka nazywa postawą (attitudes). „[...] postaw ludzi nie można przewidzieć z całkowitą ufnością. Niektóre silne korelacje można znaleźć między niektórymi czynnikami oraz pewnymi postawami i między poszczególnymi postawami oraz rodzajami zachowań językowych, ale wysiłki zmierzające do ustalenia zależności [...] zostały udaremnione 
Tabela 2. Czynniki wpływające na idiolekt

\begin{tabular}{|c|c|c|}
\hline \multirow{2}{*}{$\begin{array}{c}\text { CZYNNIK } \\
\text { WPEYWAJĄCY } \\
\text { NA IDIOLEKT }\end{array}$} & \multicolumn{2}{|c|}{ ROZMÓWCA } \\
\hline & DS & ZS \\
\hline język prymarny & polski & polski \\
\hline $\begin{array}{c}\text { język } \\
\text { sekundarny }\end{array}$ & ukraiński & ukraiński \\
\hline język przodków & polski & polski \\
\hline $\begin{array}{l}\text { język kontaktów } \\
\text { sąsiedzkich } \\
\text { przed } \\
\text { przesiedleniem }\end{array}$ & ukraiński & polski i ukraiński \\
\hline $\begin{array}{l}\text { język kontaktów } \\
\text { sąsiedzkich po } \\
\text { przesiedleniu }\end{array}$ & $\begin{array}{l}\text { polski i ukraiński } \\
\text { Komentarz: Rozmówczyni wska- } \\
\text { zuje, że jej językiem kontaktów są- } \\
\text { siedzkich po przesiedleniu był język } \\
\text { polski. Wskazuje jednak, że nowi } \\
\text { uczniowie kalečyl'i język polski, ńe } \\
\text { bardzo dôbže mówili po polsku, bo } \\
\text { skont | jak sam’i rudźicey ńe umel'i. } \\
\text { Zatem należy przypuszczać, że języ- } \\
\text { kiem kontaktów sąsiedzkich były ję- } \\
\text { zyk polski i język ukraiński (lub jego } \\
\text { odmiany). }\end{array}$ & $\begin{array}{l}\text { polski i ukraiński } \\
\text { Komentarz: Według zs po przesiedleniu } \\
\text { mieszkańcy Świętojańska po pôlsku mówili. } \\
\text { Wypełniając obowiązki listonosza, spotkał } \\
\text { się z tym, że kobiety mówiły po tym svojim, } \\
\text { używając takich słów, jak červo i xuba. } \\
\text { Rozmówca nie znał dobrze języka ukra- } \\
\text { ińskiego, przez co nie rozumiał wszyst- } \\
\text { kich zwrotów. Należy przypuszczać, że ję- } \\
\text { zykiem kontaktów sąsiedzkich były język } \\
\text { polski i ukraiński (lub jego odmiany). }\end{array}$ \\
\hline $\begin{array}{l}\text { wykształcenie } \\
\text { przed } \\
\text { przesiedleniem }\end{array}$ & $\begin{array}{l}\text { ukończone } 3 \text { klasy } \\
\text { w języku rosyjskim } \\
\text { Komentarz: Rozmówczyni wskazu- } \\
\text { je: rano była rel'ig'ija fškôle | to po pôl- } \\
\text { sku muv'iło śe paćeš | a po pouudńu | } \\
\text { jak śe šło | vyxodźiuo ze škouxy|po ru- } \\
\text { sku teš paćeš był. Czas uczęszczania } \\
\text { do szkoły przed przesiedleniem Ds } \\
\text { przypadł na okres okupacji sowiec- } \\
\text { kiej (1939-1941), dlatego jako język } \\
\text { szkoły został wskazany rosyjski. }\end{array}$ & $\begin{array}{l}\text { ukończone } 3 \text { klasy } \\
\text { w języku ukraińskim lub polskim } \\
\text { Komentarz: W czasie wywiadu nie uzy- } \\
\text { skano informacji, w jakim języku naucza- } \\
\text { no w szkole. Ze względu na to, że okres } \\
\text { nauczania zs przypada na okres okupacji } \\
\text { niemieckiej (1941-1943), podczas której } \\
\text { podstawowa edukacja odbywała się w ję- } \\
\text { zyku ukraińskim, prawdopodobnie języ- } \\
\text { kiem nauczania w szkole był język ukraiń- } \\
\text { ski. Rozmówca wskazuje jednak, że język }\end{array}$ \\
\hline
\end{tabular}

przez złożoność ludzkich zachowań językowych [...] postawy zależą od konkretnej kultury i położenia regionalnego. [...] jeden człowiek może reprezentować dwie lub więcej postaw" (Thomason 2001: 22, 33; tłum. G.A.-Ż.). Analiza biografii językowej pozwala na określenie nastawienia do języka w relacji do innych języków. Analizowanie doświadczeń osobistych przesiedleńców z dawnych wschodnich województw II Rzeczypospolitej w kontekście społeczno-historycznym, może wnieść nową wiedzę w badaniach nad nastawieniem do języków. 


\begin{tabular}{|c|c|c|}
\hline & & $\begin{array}{l}\text { ukraiński rozumiał tylko trochę. To mog- } \\
\text { łoby oznaczać, że nauczanie w szkole od- } \\
\text { bywało się w języku polskim. Możliwe } \\
\text { jest także, że w szkole używano dialek- } \\
\text { talnych bądź gwarowych odmian języka } \\
\text { ukraińskiego. }\end{array}$ \\
\hline $\begin{array}{l}\text { wykształcenie po } \\
\text { przesiedleniu }\end{array}$ & $\begin{array}{l}\text { ukończone liceum pedagogiczne } \\
\text { w Ośnie Lubuskim }\end{array}$ & $\begin{array}{l}\text { ukończona } 7 \text { klasa szkoły podstawowej } \\
\text { w Krzeszycach }\end{array}$ \\
\hline $\begin{array}{l}\text { wykonywany } \\
\text { zawód }\end{array}$ & $\begin{array}{l}\text { nauczycielka klas początkowych } \\
\text { i języka rosyjskiego }\end{array}$ & $\begin{array}{l}\text { pomocnik w gospodarstwach rolnych, } \\
\text { listonosz } \\
\text { Komentarz: Idiolekt zs kształtował się tak- } \\
\text { że pod wpływem pracy zawodowej. Jego } \\
\text { życie w regionie lubuskim skupione było } \\
\text { głównie na dwóch rodzajach działalności. } \\
\text { Pierwsza to pomoc w gospodarstwach - } \\
\text { w latach 1952-1953 (17-18 lat) rozmów- } \\
\text { ca miał podczas prac styczność z różnymi } \\
\text { odmianami polszczyzny. Chodzi tu m.in. } \\
\text { o przesiedleńców z województwa wiel- } \\
\text { kopolskiego oraz przybyłych z centralnej } \\
\text { Polski. }\end{array}$ \\
\hline $\begin{array}{l}\text { język domu } \\
\text { po założeniu } \\
\text { rodziny }\end{array}$ & polski & polski i mowa chachłacka \\
\hline $\begin{array}{l}\text { nastawienie do } \\
\text { języków }\end{array}$ & $\begin{array}{l}\text { polski - pozytywne } \\
\text { ukraiński - pozytywne } \\
\text { rosyjski - pozytywne } \\
\text { Komentarz: Na pozytywne nasta- } \\
\text { wienie do języka rosyjskiego miał } \\
\text { wpływ zawód wykonywany przez } \\
\text { rozmówczynię. Podczas wywiadów } \\
\text { kilkukrotnie wspominała o swo- } \\
\text { im perfekcyjnym języku rosyjskim. } \\
\text { Wiąże również z rosyjskim dobre } \\
\text { wspomnienia, czyli pracę w szkole. }\end{array}$ & $\begin{array}{l}\text { polski - pozytywne } \\
\text { ukraiński - pozytywne } \\
\text { Komentarz: W lipcu } 2014 \text { roku razem } \\
\text { z dr Anną Żebrowską podjęłyśmy próby } \\
\text { przeprowadzenia wywiadu w języku ukra- } \\
\text { ińskim, lecz się nie powiodły. Rozmówca } \\
\text { nie rozumiał zadawanych pytań i nie umiał } \\
\text { na nie odpowiadać. Wnioskuję, że nastąpi- } \\
\text { ła atrycja językowa języka sekundarnego } \\
\text { deklarowanego przed przesiedleniem. To } \\
\text { też może być potwierdzeniem, że rozmów- } \\
\text { ca w dzieciństwie znał język ukraiński, ale } \\
\text { bardzo słabo. Sam mówi: po to ukrajińsku } \\
\text { ja rozumiauem troxu. }\end{array}$ \\
\hline & \multicolumn{2}{|c|}{$\begin{array}{l}\text { Komentarz: Podczas wielogodzinnych rozmów z DS i zs nie było sytuacji, w której } \\
\text { o danym języku wypowiadaliby się negatywnie. Wnioskuję zatem, że nastawienie do } \\
\text { wymienionych języków jest pozytywne. Wiąże się to zapewne z tym, że język ukra- } \\
\text { iński (lub jego odmiany regionalne) funkcjonował w regionie lubuskim. }\end{array}$} \\
\hline
\end{tabular}


Sytuację, którą prezentuje tabela 1, wskazuje na częstsze występowanie analizowanych cech fonetycznych w idiolekcie DS. Z przeliczenia wartości procentowych wynika, że w idiolekcie ZS występuje $78 \%$ realizacji cech DS. Widoczne różnice są zależne od biografii językowych rozmówców - od przebiegu życia i kontaktów językowych.

Wspólnymi czynnikami wpływającymi na idiolekty obojga rozmówców są: języki prymarny i sekundarny, język przodków i nastawienie do języków. Różnice wskazane w języku kontaktów sąsiedzkich przed przesiedleniem i po nim, różnice w wykształceniu oraz w wykonywanym zawodzie i języku używanym w domu po założeniu rodziny znacząco wpłynęły na idiolekty moich rozmówców.

Biografia językowa jest ściśle związana z przebiegiem życia rozmówcy. Idiolekt kształtuje się przez cały okres życia jednostki. Badanie biografii językowej i jej wpływu na idiolekt wymaga dokładnej analizy sytuacji socjolingwistycznej, w której znajdował się (i znajduje) rozmówca. Celem tego artykułu była odpowiedź na pytanie, czy biografia językowa ma wpływ na idiolekt jednostki. Na podstawie idiolektów dwojga rozmówców przesiedlonych $\mathrm{z}$ terenu dawnego województwa tarnopolskiego wskazałam różnice w realizacji wybranych cech fonetycznych. Zaprezentowane czynniki wpływające na idiolekt nie są wyczerpaną listą, lecz pierwszą próbą ich omówienia.

\section{Bibliografia}

Babbie E. 2009: Podstawy badań społecznych, przeł. W. Betkiewicz, Wydawnictwo Naukowe PWN, Warszawa.

Bartnicka-Dąbkowska B. 1965: Podstawowe wiadomości z dialektologii polskiej ź́wiczeniami, red. B. Wieczorkiewicz, wyd. 2 , Państwowe Zakłady Wydawnictw Szkolnych, Warszawa.

Blommaert J. 2008: Language, asylum, and the national order, „Urban Language \& Literacies”, vol. 50, s. 2-21.

Blommaert J., Backus A. 2013: Superdiverse Repertoires and the Individual, [w:] I. de Saint-Georges, J.-J. Weber (red.), Multilingualism and Multimodality. Current Challenges for Educational Studies, Sense Publishers, Rotterdam-BostonTaipei, s. 11-32.

Busch B. 2017: Expanding the Notion of the Linguistic Repertoire: On the Concept of Spracherleben - The Lived Experience of Language, „Applied Linguistics”, vol. 38(3), s. 340-358.

Cooley Ch.H. 1992: Grupy pierwotne, [w:] J. Mucha, Cooley, Wydawnictwo „Wiedza Powszechna”, Warszawa, s. $209-214$.

Drzazgowski M. 1992: O nazwie chachłacka mowa, [w:] K. Handke (red.), Słowiańskie pogranicza językowe. Zbiór studiów, Slawistyczny Ośrodek Wydawniczy, Warszawa, s. 29-35.

Dzięgiel E. 2003: Polszczyzna na Ukrainie. Sytuacja językowa w wybranych wsiach chłopskich i szlacheckich, Wydawnictwo Naukowe Semper, Warszawa.

Dzięgiel E. 2017: Odmiany terytorialne i społeczne współczesnego języka polskiego na Ukrainie, „LingVaria” 12 (24), s. 199-210. EJO: Encyklopedia językoznawstwa ogólnego, red. K. Polański, Zakład Narodowy im. Ossolińskich, Wrocław-WarszawaKraków 1999.

Franceschini R., Miecznikowski J. (red.) 2004: Laben mit mehreren Sprachen. Sprachbiographien. Vivre avec plusieurs langues. Sprachbiographien. Biographies langagières, Peter Lang, Bern-Berlin.

Głuszkowski M. 2011: Socjologiczne i psychologiczne uwarunkowania dwujęzyczności staroobrzędowców rejonu suwalsko-augustowskiego, Wydawnictwo Naukowe Uniwersytetu Mikołaja Kopernika, Toruń.

Głuszkowski M. 2013: Idiolektalne zróżnicowanie przełączania kodów w dwujęzyczności starowierców regionu suwalsko-augustowskiego, „Acta Baltico-Slavica”, z. 37, s. 265-275.

Golachowska E. 2006: Język i kultura mieszkańców wsi włościańskich i szlacheckich dawnej ziemi drohickiej na Podlasiu. Studium socjolingwistyczne, Slawistyczny Ośrodek Wydawniczy, Warszawa. 
Grek-Pabisowa I. 1983: Słownictwo rosyjskiej wyspy gwarowej staroobrzędowców mieszkających w Polsce. Rozwój i stan dzisiejszy, Zakład Narodowy im. Ossolińskich, Wrocław.

Grek-Pabisowa I., Maryniakowa I. 1999: Współczesne gwary polskie na dawnych kresach północno-wschodnich, Slawistyczny Ośrodek Wydawniczy, Warszawa.

Halliday M.A.K. 1968 (1964): The sers and uses od language, [w:] J. Fishman, Readings in the sociology of language, Mouton \& Co, The Huge, s. 56.

Handke K. 1993: Przedmowa, [w:] Region i regionalizm - pojęcia i rzeczywistość, Slawistyczny Ośrodek Wydawniczy, Warszawa, s. 7-11.

Hermanns H. 1987: Narrative interview: A new tool for sociological field research, „Folia Sociologica”, vol. 13, s. 43-56.

Hoffmann-Riem Ch. 1980: Die Sozialforschung einer interpretativen Soziologie, „Kölner Zeitschrift für Soziologie und Sozialpsychologie", vol. 2, s. 339-372.

Homa E. 1979: Współczesne gwary Pomorza Środkowego. Studium socjolingwistyczne. Cz. 1, Wyższa Szkoła Pedagogiczna, Słupsk, s. 5-39, 252-271.

Jankowiak M. 2009: Gwary białoruskie na Łotwie w rejonie krasławskim. Studium socjolingwistyczne, Slawistyczny Ośrodek Wydawniczy, Warszawa.

Kaufmann J.C. 2010: Wywiad rozumiejący, tłum. A. Kapciak, Oficyna Naukowa, Warszawa.

Klatta P. 2012: Zróżnicowanie osadnicze obszaru województwa lubuskiego, [w:] B.A. Orłowska, K. Wasilewski (red.), Mniejszości regionu pogranicza polsko-niemieckiego. Separacja, adaptacja, integracja, asymilacja, Wydawnictwo Państwowej Wyższej Szkoły Zawodowej, Gorzów Wielkopolski, s. 127-135.

Kłoskowska A. 2012: Kultury narodowe u korzeni, Wydawnictwo Naukowe PwN, Warszawa, s. 79-299.

Kurek H. 1990: Metodologia socjolingwistycznego badania fonetyki języka mówionego środowisk wiejskich (na przykładzie kilku wsi Beskidu Niskiego), nakł. Uniwersytetu Jagiellońskiego, Kraków.

Libura A. 2014: Atrycja języka odziedziczonego, [w:] A. Dąbrowska, U. Dobesz (red.), 40 lat wrocławskiej glottodydaktyki polonistycznej. Teoria i praktyka, Oficyna Wydawnicza Atut - Wrocławskie Wydawnictwo Oświatowe, Wroclaw, s. 303-312.

Lipińska E., Seretny A. 2012: Między językiem ojczystym a obcym. Nauczanie i uczenie się języka odziedziczonego na przykładzie szkolnictwa polonijnego w Chicago, Księgarnia Akademicka, Kraków.

Martinet A. 1961: A Functional View of Language, Oxford Clarendon Press, Oxford.

Meng K. 2004: Russlanddeutsche Sprachbiographien - Rückblick auf ein Projekt, [w:] R. Franceschini, J. Miecznikowski (red.), Laben mit mehreren Sprachen. Sprachbiographien. Vivre avec plusieurs langues. Sprachbiographien. Biographies langagières, Peter Lang, Bern-Berlin, s. 97-117.

Miśkiewicz A. 2009: Tatarzy na Ziemiach Zachodnich Polski w latach 1945-2005, Wojewódzka i Miejska Biblioteka Publiczna im. Zbigniewa Herberta, Gorzów Wielkopolski.

Montrul S. 2002: Incomplete Acquisition and Attrition of Spanish Tense/Aspect Distinctions in Adult Bilinguals, „Bilingualism: Language and Cognition", vol. 5(1), s. 40.

Morita K. 2006: Przemiany socjolingwistyczne w polskich społecznościach na Litwie (region trocki) $i$ Białorusi (region iwieniecki). Studium porównawcze, Slawistyczny Ośrodek Wydawniczy, Warszawa.

Norton B. 2000: Identiti and language learning: social processes and educational practice, Longman, New York.

Paryl W. 1978: Oddziaływanie języka literackiego na niektóre dialekty Ziem Zachodnich, „Studia Linguistica” IV, s. 71-81.

Piotrowski A., Ziółkowski M. 1976: Zróżnicowanie językowe a struktura społeczna, Państwowe Wydawnictwo Naukowe, Warszawa.

Polinsky M. 1995: Cross-Linguistic Parallels in Language Loss, „Southwest Journal of Linguistics”, vol. 14(1-2), s. 88-123.

Polinsky M., Kagan O. 2007: Heritage Languages: In the «Wild» and in the Classroom, „Language and Linguistics Compass", vol. 1(5), s. 368-395.

Rieger J., Cechosz-Felczyk I., Dzięgiel E. 2007: Język polski na Ukrainie w końcu Xx wieku, cz. 2, Polszczyzna w Lwowskiem, Żytomierskiem i na Podolu. Teksty, Wydawnictwo Lexis, Kraków, s. 18-20, 28-32, 39-42, 50-53.

Riehl C.M. 2009: Sprachkontaktforschung. Eine Einführung, Gunter Narr Verlag, Tübingen.

Romaine S. 1989: Bilingualism, Basil Blackwell, Oxford.

Schütze F. 1977: Die Technik des narrativen Interviews in Interaktionsfeldstudien dargestell an einem Projekt zur Erforschung kommunalen Machtstrukturen, [w:] Arbeitsberichte und Forschungsmaterialien, Universität Bielefeld, der Fakultät für Soziologie der Universität, Bielefeld, vol. 1, s. 1-62.

Schütze F. 1983: Biographieforschung und narrativer Interview, „Neue Praxis”, vol. 13, s. 283-293. 
Schütze F. 1984: Kognitive Figuren des autobigraphfischen Stegrelferzählens, [w:] M. Kohli, G. Robert (red.), Biographie und Soziale Wirklichkeit: neue Beiträge und Forschungsperspektiven, Metzler, Stuttgart, s. 78-117.

Schütze F. 1987: Das narrative Interview in Interaktionsfeldstudien I, Studienbrief der Fernuniversität Hagen, Hagen.

Smułkowa E. 2002: Frekwencja tekstowa białoruskich typów akcentuacyjnych rzeczowników (Na podstawie próbek tekstów gwarowych z okolicy Witebska i Sokółki), [w:] eadem, Białoruś i pogranicza. Studia o języku i społeczeństwie, Wydawnictwa Uniwersytetu Warszawskiego, Warszawa, s. 69-84.

Thomason S.G. 2001: Language contact, University Press, Edinburgh.

Thompson P. 1978: The Voice of the Past. Oral History, Oxford University Press, Oxford.

Trempała J. (red.) 2011: Psychologia rozwoju człowieka. Podręcznik akademicki, Wydawnictwo Naukowe PWN, Warszawa.

Urbańczyk S. 1956: Rozwój języka narodowego. Pojęcie i terminologia, [w:] Z. Stieber (red.), Z dziejów powstawania języków narodowych i literackich, Państwowe Wydawnictwo Naukowe, Warszawa, s. 9-36.

Valdés G. 1995: The Teaching of Minority Languages as «Foreign» Languages: Pedagogical and Theoretical Challenges, „Modern Language Journal", vol. 79(3), s. 299-328.

Valdés G. 2000: Teaching Heritage Languages: An Introduction for Slavic-Language-Teaching Professionals, [w:] O. Kagan, B. Rifkin (red.), Learning and Teaching of Slavic Languages and Cultures: Toward the 21st Century, Slavica Publishers, Bloomington, s. 375-403.

Weinreich U. 1968: Is a Structural Dialectology Possible, [w:] J.A. Fishmann (red.), Readings in the Sociology of Language, Mouton \& Co, The Hague, s. 306.

Weinreich U. 1970: Languages in Contact. Findings and Problems, Mouton, The Hague-Paris,

Wyderka B. 2001: Przemiany językowe na ziemiach zachodnich i północnych, [w:] S. Gajda (red.), Najnowsze dzieje języków słowiańskich. Język polski, Uniwersytet Opolski, Opole, s. 460-476.

Zawadowski L. 1961: Fundamental relations in language contact, „Biuletyn Polskiego Towarzystwa Językoznawczego” xx, S. $3-26$.

Zdaniukiewicz A. 1972: Procesy integracji językowej na Ziemiach Zachodnich i Północnych w świetle analizy ilościowej, „Prace Filologiczne" XXIII, s. 283-288.

Zielińska A. 2002: Polska mniejszość na Litwie Kowieńskiej. Studium socjolingwistyczne, Slawistyczny Ośrodek Wydawniczy, Warszawa.

Zielińska A. 2012: Wielojęzyczność w województwie lubuskim. Stan współczesny, [w:] B.A. Orłowska, K. Wasilewski (red.), Mniejszości regionu pogranicza. Separacja, adaptacja, integracja, asymilacja, Wydawnictwo Państwowej Wyższej Szkoły Zawodowej, Gorzów Wielkopolski, s. 13-23.

Zielińska A. 2013: Mowa pogranicza. Studium o językach i tożsamościach w regionie lubuskim, Slawistyczny Ośrodek Wydawniczy, Warszawa.

Zielińska A. 2018: Biografie językowe osób bilingwalnych z polsko-niemieckiego pogranicza, [w:] Z. Greń (red.), „Z Polskich Studiów Slawistycznych", seria 13, t. 2, Wydawnictwo Naukowe Uniwersytetu im. Adama Mickiewicza, Poznań, s. $359-268$.

Summary

\section{Impact of language biography on the idiolect. Speech of people resettled from the province Tarnopol region to the Lubusz region}

Keywords: language biography, idiolect, Lubusz region, resettlement.

The article presents language biographies and idiolects of two people resettled after 1945 from the province Tarnopol to the Lubusz region. The reconstruction of each language biography considers different life stages (childhood, early school years, adolescence, adulthood, old age). After presenting the linguistic biographies of the informants examples of selected phonetic features found in their idiolects as well as their numerical and percentage breakdown have been shown. The next section offers a discussion of the impact of language biography on the idiolect of each informant. 